\title{
Development Strategy of Wealthy Customers in Chinese Commercial Banks
}

\author{
Tianying Zhou, Master Candidate \\ SHU-UTS SILC Business School, Shanghai University
}

doi: 10.19044/esj.2016.v12n25p145 URL:http://dx.doi.org/10.19044/esj.2016.v12n25p145

\begin{abstract}
Wealth management business is an old and young business. In terms of wealth management, it begins from the social class when wealth allocation becomes divided. Wealth management in modern sense originated in Napoleon Era in France. Napoleon gave his wealth to bankers of Switzerland to manage, which opened a precedent for wealth management. As far as Chinese commercial banks are concerned, wealth management business provides services to help wealthy customers realize the value of their assets. This paper reviews current situations of wealth management business in Chinese commercial banks and investigates customer development strategy.
\end{abstract}

Keywords: Commercial Banks, Wealth Management, Customer Development

\section{Current Situation}

According to "2015 World Wealth Report" by Credit Suisse ${ }^{[1]}$, total household wealth of China in 2015 reached $\$ 22.8$ trillion, with \$ 1.5 trillion increase from last year. China's total household wealth has exceeded that of Japan and ranked second in the world after the United States. In recent years, the number of Chinese billionaires has been growing rapidly. According to statistics, the number of Chinese millionaires is more than 1 million. The number of ultra-high-net-worth (UHNW) individuals, whose personal assets are more than $\$ 50$ million, is up to 12 million. The number of China's UHNW is just after that of the United States'. The report shows that the number of global middle-class adults has increased to 664 million now compared with 524 million in 2000. It is equivalent to $14 \%$ of the adult population. Although China's middle-class adult is only $11 \%$ of China's adult population, it is the world's largest in absolute terms, reaching 109 million people, more than that of the US whose middle-class adult population is 92 million.

According to the distribution of branded customer of BOCOM's Taizhou branch, intermediate customers account for up to $90.23 \%$ while 
upper-level customers account for only 9.54\%. Private banking customers account for only $0.23 \%$. Combining its customer information, only $9.77 \%$ of its customers contribute to the profit of Bank of Jiangsu's Taizhou branch. This indicates that more than $90 \%$ of ordinary bank customers consume a lot of resources, and less than $10 \%$ of customers, who are high-end customers of the bank, create profit. This situation does not match the "Pareto rule".

\section{SWOT Analysis}

In essence, SWOT (strength, weakness, opportunity and treat) analysis is a method to view internal and external conditions of the enterprise integration. This paper uses SWOT analysis to compare differences between Chinese commercial banks and foreign commercial banks to examine Chinese commercial banks's wealth management. The results of the SWOT analysis can reflect Chinese customer development management strengths and weaknesses, opportunities and threats of commercial banks wealth management client development. Chinese commercial banks wealth management department may use such information to make more effective decisions for future development.

Strength

1. Get the Chinese private banking franchise issued by China Banking Regulatory Commission (CBRC)

2. Build relatively independent management system

3. Acquire rising asset size, customer base, business development phenomenon

4. Establish wealth management brand image

5. Build better foundation of networking

6. Enhance effectiveness of services

7. Proactive risk prevention and decide strategies for business security

8. Integrate IT platform efficiently to provide technical support

9. Build overseas development strategy to provide global investment opportunities

Weakness

1. High-end customer service lacks experience

2. The method of high-end customer service is passive

3. High-end customer service lacks comprehensive talents

4. The system of high-end customer service has not completed

5. The marketization of operation and management system is inappropriate

6. High-level asset management capability is not strong 
Orientation

1. The growing market of Chinese high-end customers

2. The global economic crisis has brought unprecedented opportunities for development to Chinese commercial banks

3. Regulatory policies to encourage private banking business Trend development and innovation of products

1. The competition of high-end customer service market is intense

2. Financing conception of Chinese high-end customers is immature

3. Mode of segregate management leads to restrictive business

4. Strict foreign exchange control limits overseas investment

\section{Strategies}

Olejniczak (2010) indicates that commercial bank wealth management customer development refers to commercial banks acquiring their customer base through marketing to fulfill their business scale and profit requirements, development direction with its abundant resources of high-quality capital and rich financial products, professional services, and software and hardware facilities $^{[2]}$. It is a progress to acquire customers, mine and maintain deep relation between banks and customers. Customer development department is responsible for marketing, integrated management, including customer research, customer relation management, pricing management, and channel development.

\section{Guidance}

First, the development of customer relation generally has four phases: explore period, form period, stable period and degenerate period. Each period represents a different level of customer loyalty. The four phases are illustrated in Figure 1.

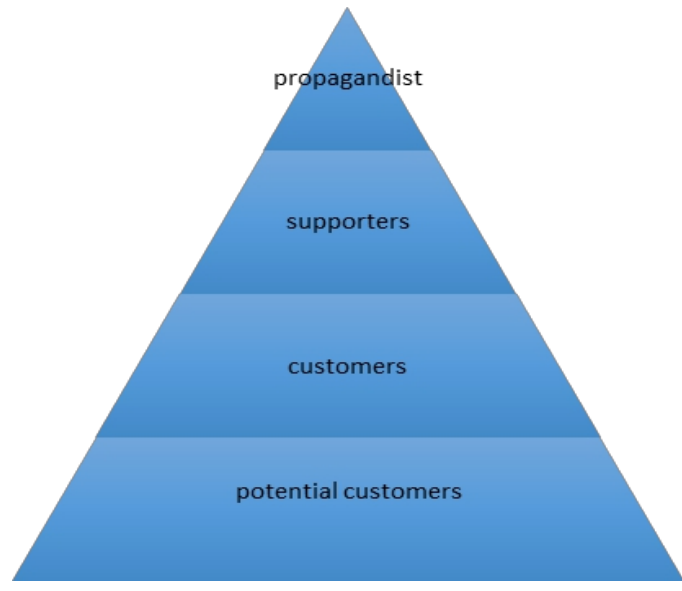

Figure 1 Pyramid of Customers’ Loyalty 
Located at the bottom of the pyramid is the potential target customer base of enterprise, whose loyalty to the enterprise has not formed. Only through efforts to develop relations with them can these potential customers be transformed into customers. In this case, customer loyalty corresponds to the explore period. After passing explore period, customers' loyalty may rise because of enterprises' attempt. Relation between customers and enterprises begins to mature. When loyalty keeps increasing, customers become supporters of enterprises, and thus become advocates. The relation between the two proceeds to the stable period, when customer loyalty is the highest among four periods of customer relation development. Customers do not only feel great satisfaction with the bilateral relations, but also they promote and recommend means for enterprises to develop new customers. With increased levels of customer loyalty, Evensky (2005) indicates that the number of highend customers gradually decrease. Customer retention is not only aimed at maintaining customer relation, but also it promotes the customer relation to a higher level ${ }^{[3]}$.

\section{Goal}

For Chinese commercial banks, personal and family's wealth management services are under increasing demand. Facing today's highly competitive wealth management market, developing proper customer development strategies will help commercial banks occupy a better market position.

\section{Responsibilities}

Based on the analysis reported by Industrial Securities, customer development has mainly the following four functions:

\section{Marketing}

This department is responsible for researching industry development and competitor dynamics. Based on their research, they make work guidelines, organize resources and implement plans. Marketing activities will also need some other resources to promote sales marketing plan.

\section{Customer Relation Management}

This department is responsible for customer relation management and personal lines of business. They need research on customers' trading characteristics, such as risk preference, investment and financial management demand. Based on their result, they will promote proper products to classified customers. Besides, according to Zhou (2008), customer relation management department is responsible for monitoring and evaluating public opinion, and improving customer service quality ${ }^{[4]}$. 


\section{Pricing Management}

Pricing management department is responsible for sales pricing and channel pricing management. They lead the pricing strategies for various types of channel business. By building scientific pricing strategies, enterprises can differentiate themselves from their competitors and enhance customer service and revenue growth.

\section{Service System Construct}

Service system includes service brand building, Automatic Foreign Exchange Allocation (AFA) platform construction, and operation system building.

\section{Strategies for Customer Development}

Referring to responsibilities of customer development department, $\mathrm{Li}$ (2009) indicates that wealth management business is essentially different from banking business ${ }^{[5]}$. Thus, accumulating customers is a relatively long process. Therefore, at the early stage, core business of wealth management should focus on mining high-end customers rather than capturing rapid growth in the number of customers in the short term. Referring to the actual experience of developed countries in Europe and North America, wealth management business needs lots of resources to build system construction, system development, staff training and customer development in the first three to five years. Such fundamental work will not produce significant outputs or profitable growth in the short term. Therefore, in order to do preliminary development of wealth management business, wealth management company should make more efforts to mine quality customers, and design and promote proper products to meet customers' need. When the business reaches a certain size, then it can gradually increase scale of business and customers, so as to enhance the quality of customers and increase the number of new customers at the same time.

Commercial banks retain their quality customers through several stages including excavate new customers, screen and maintain current customers and eliminate unqualified customers. They try to provide differentiated services to customers and create more value. As more value is created for customers, a loyal and strong customer relation will be built. In such a long process, customer relation management plays an important role. Therefore, a successful customer relation management enables customers to experience customer loyalty development up along the pyramid, eventually becoming high loyal advocates. At the end, both consumers and businesses will maximize their own value. 
During customer acquisition process, efforts to develop customer and marketing costs are not the same for different types of customers, such as potential customers and competitive customers. If a competitor can provide more value to customers, some customers will choose to transfer, but some customers will be able to maintain relations with the original enterprise because of the transfer cost. However, customer loyalty and customer relation expectation during the life cycle will be reduced. Because of this, customers can provide less profit for the enterprise. Thus, the principle, which is creating more values for customers and providing more attractive value than its competitors, will help enterprise not only retain customers, but also continuously improve customer loyalty level.

Employees of commercial banks should keep close relation with future targeted customers. They are required to initiatively provide financial information to customers and understand their financial needs. Based on customers' need, employees provide qualified services to customers and make customers satisfied with their service. The goal for employees is to let potential customers become loyal customers. Beside the efforts of employees, commercial banks should use all their resources to promote integrated marketing strategies to differentiate its band image. Development Strategies of Wealth Management Customers in Commercial Bank is illustrated in Figure 2.

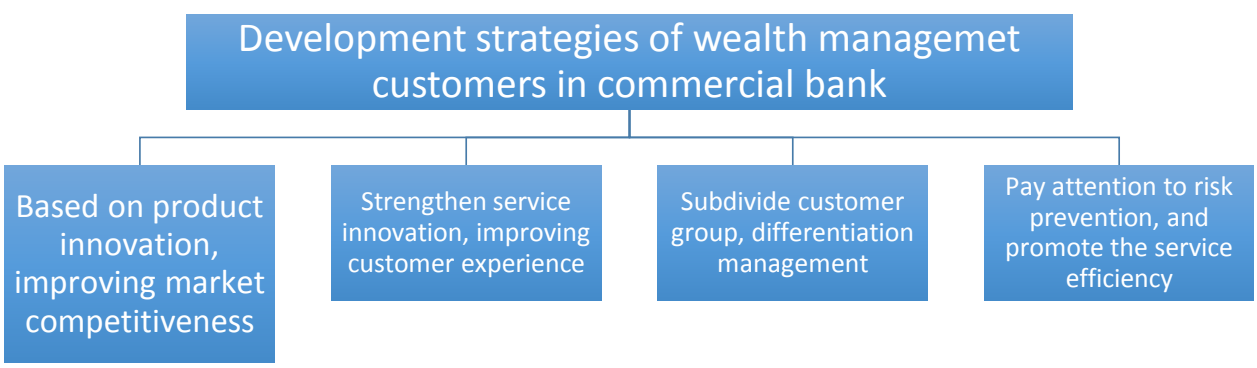

Figure 2 Development Strategies of Wealth Management Customers in Commercial Bank

\section{Implementation of Strategies \\ Providing Services to Potential Customers}

Potential customers are currently neither strategic customers of commercial banks, nor key customers of the bank. Jiang (2008) indicates that banks should use the developing perspective to view potential customers ${ }^{[6]}$. In the next few years, potential customers will grow to strategic customers or key customers of commercial banks. Therefore, banks should pay attention to such 
potential customers, track customer characteristics such as financial values, financial goals, and their changing trend. Such potential customers will help banks achieve better market position in the future.

\section{Differentiate Financial Products to Meet Customers' Need}

Different types of customers contribute differently to banks. In addition, different types of customers have various financial needs and values. If commercial banks can provide customized financial products to meet customers' unique needs, banks can reduce costs and increase quality of service at the same time. Also, satisfying the needs of customers helps promote commercial banks themselves.

Because high-end customers have two characteristics, i.e., value adding need and risk aversion, commercial banks can design and provide more developed value-added products and services, thus enhancing high-end customers' financial planning needs. Efforts can be made to allocate asset portfolio, focusing on value-added services. Commercial banks should provide appropriate products and services according to customer value, occupational characteristics and life cycle. Implementation of differentiated management should be conducted consistently.

\section{Establish "Customer-Centered" Service Concept}

Ma (2011) indicates that for Chinese affluent customers, they have little awareness of financial investment and financial management ${ }^{[7]}$. Thus, commercial banks should take full advantage of this phenomenon. Banks should treat wealthy customers' needs as the core of the work. Through using "one to one" and "team" approach, providing specialized account manager (expert), explaining and promoting financial investments can these customers better obtain their needs in the shortest time.

For example, Communications Bank of China (BOCOM) makes assortment for its private banking customers, upper-level customers and other customers. Also, it establishes a " $1+1+1$ " brand services team (one professor of head office's individual wealth management department + one expert of branch's individual wealth management department + one privilege account manager). BOCOM provides high quality services, good market brand and efficient service team. For upper-level customers, whose asset is more than 50 million, BOCOM provides "six exclusive" services, such as privilege account manager, exclusive VIP financial center and the green channel, exclusive financial products, exclusive price promotions, exclusive accounts, and exclusive value-added services.

Continually Optimize Business Process

Commercial banks can also set up green channel, set VIP service counter to ensure that high-end customers have more convenience, let high- 
end customer credit limit gradually improve, and issue top-level credit cards to meet needs of high-end customers. Such services may gradually enhance high-end customers' trust of banks. As a result, a stable partnership will be formed.

\section{Conclusion}

Overall, commercial banks are currently in the process of transformation. The development of customers in wealth management plays an irreplaceable role. Also, it has become the core of competition between foreign banks and Chinese commercial banks. China's wealth management market still has great potential for development. China's commercial banks should apply differentiated marketing strategies to different customers, meet their unique needs, and maintain a stable relation.

\section{References:}

Credit Suisse, Credit Suisse Global Wealth Database, 2015

DorotaBednarska-Olejniczak. The Quality of Private Banking Services as Perceived by Polish Customers. Department of Marketing in Management, Wroclaw University of Economics, Komandorska, 2010:118-120

Harold R.Evensky, Wealth Management: The Financial Advisor's Guide to Investing and Managing Your Client's Assets, USA, MacGraw-Hill, 2005:112-130

Jieru Zhou, Modern Relationship of customer management, Shanghai Jiao Tong University Press, 2008 (In Chinese)

Weijun Li, The Situation of Private Bank in China, Investment and Research, 2009: 14-18 (In Chinese)

Jing Jiang, Personal Strategy in a New Area of Finance, Horizon Research Group, 2008 (In Chinese)

Jun Ma, Customer Management in Personal Business of Bank, Manager, 2011:59 (In Chinese ) 